\title{
THE ROLE OF SOCIO-ECONOMIC DIAGNOSTICS IN AN ENTERPRISE MANAGEMENT SYSTEM
}

\author{
Olga Melnyk ${ }^{1}$, Andrii Todoshchuk ${ }^{2}$, Marta Adamiv ${ }^{3}$ \\ Lviv Polytechnic National University, Ukraine
}

\begin{abstract}
The purpose of the article is to justify the role of socio-economic diagnostics of the enterprise as an information base for managerial decision-making in the conditions of integration and globalization processes. The subject of the study is the theoretical and applied principles of socio-economic diagnostics of the enterprise's activity at the national and international levels. The methodology of the research is to identify the key priority accents of the socio-economic diagnostics of the enterprise's activity, taking into account the integration and globalization challenges. On the example of Ukraine as a country on the path of European integration, the problems in the field of socio-economic diagnostics of enterprise's activity are investigated and identified, which are connected with the existence of discrepancies with recognized international diagnostic experience. The necessity of unification of diagnostic procedures is proved in order to establish, deepen, and expand the effective cooperation of domestic enterprises with foreign partners, which will facilitate the activation of the European integration process. It is established that leading players of international markets make decisions about the cooperation establishment on the basis of diagnostic conclusions, which are formed by such known international credit rating agencies as Moody's, Standard \& Poor's, Fitch. Thus, the best international diagnostic experience has been researched and analysed on the example of the recognized international credit rating agencies Moody's, Standard \& Poor's, Fitch. It is determined that at the present stage the diagnostics of the financial status of the enterprise is the priority kind of socio-economic diagnostics within the different complex diagnostic objectives. The results of the study were the development and substantiation of a unified methodology for diagnosing the financial status of the enterprise, which can be used by subjects from different countries. The proposed methodology is based on the consideration of the classical diagnostic technology, the adequate composing the national and international diagnostic experience, taking into account the integration and globalization conditions, the use of internationally recognized diagnostic terminology. In particular, within the framework of the developed methodology of diagnostics of financial status of the enterprise, it is proposed to calculate four groups of financial indicators: profitability, liquidity, financial independence and business activity. By comparison of obtained actual values of indicators with the adequate criteria, an identification database for diagnostics of types of financial status of the enterprise was developed, including risk-free status, destabilization status, pre-crisis status, the status of technical defaults, and the status of actual default. The practical value of the obtained results of the study is to enable the business structures of different countries to implement the unified diagnostic procedures and thus operate a single information base during managerial decision-making about establishing or expanding cooperation. This prevents misunderstandings during cooperation, gives an opportunity to receive the same diagnostic results and unifies their interpretation. The novelty of the results of the study is to improve and standardize the methodological, indicative, identification, and interpretive provision of the diagnostics of the financial status of the enterprise, based on taking into account the best recognized international diagnostic experience, as well as integration and globalization conditions and challenges.
\end{abstract}

Key words: socio-economic diagnostics, indicators, financial status, foreign economic activity, management decisions

JEL Classification: G32, G33, F10, M10

\footnotetext{
Corresponding author:

${ }^{1}$ Department of Foreign Trade and Customs, Lviv Polytechnic National University.

E-mail: olia_melnyk@ukr.net

${ }^{2}$ Department of Foreign Trade and Customs, Lviv Polytechnic National University.

E-mail: a.todoshchuk@gmail.com

${ }^{3}$ Department of Foreign Trade and Customs, Lviv Polytechnic National University.

E-mail:marta_adamiv@i.ua
} 


\section{Introduction}

In the conditions of intensification of integration and globalization processes in the world, the importance of socio-economic diagnostics at all levels of the national and international economies is significantly growing. The successful establishment and further development of relations between domestic and foreign partners at different levels (state and local authorities, rating agencies, financial and credit institutions, consulting and audit organizations, investors, intermediaries, business structures) require a complex, representative, relevant, and objective information base that is the result of targeted diagnostic procedures. At the present stage in the international space, there is the activation of foreign trade cooperation between economic entities of different countries of the world. On the example of Ukraine in the context of European integration, we can observe the intensification of cooperation with the European Union, which today is Ukraine's largest trade partner with a share of $44.4 \%$ in total export of goods. In particular, in the first quarter of 2018, the export of goods from Ukraine to the European Union was $\$ 11.4$ billion and increased by $10.3 \%$ compared with the first quarter of 2017. The number of Ukrainian exporting enterprises to European markets in the first quarter of 2018 was 8,624 companies, which is 526 enterprises more than in the first quarter of 2017 (Mykolska, 2018).

In the context of countries that are on the path to European integration, including Ukraine, socioeconomic diagnostics is a powerful information tool of grounded decision-making for entering European markets, establishing cooperation with foreign partners, increasing competitiveness, investment attractiveness, and ensuring progressive development. The result of the implementation of targeted diagnostic procedures is not only the quantitative data, but also the qualitative information that interprets the current and retrospective status of the diagnosed object, prospective opportunities and threats of its development, and also reflects the detailed recommendations for further vectors of functioning.

It should be noted that in modern conditions of integration and globalization, socio-economic diagnostics should be based on a unified methodological, indicator, criterion, identification, and interpretation basis, which will be unified during using by business entities from different countries in order to establish and expand their cooperation. Considering the national and best international recognized practices of socioeconomic diagnostics of enterprises according to different parameters, it should be noted that there are significant differences in the diagnostic technologies and tools used by domestic and foreign subjects, as well as groundlessness, non-harmony, and non-adaptation to international standards of domestic diagnostic techniques. It causes a lot of problems connected with the formation of different diagnostic conclusions, interpretation of diagnostic results and, as a result, the emergence of misunderstandings between different partners, which complicates and impedes effective cooperation, reduces the interest of counteragents in interaction, etc.

All of above-mentioned determines the purpose of the research that is related to the substantiation of the role of socio-economic diagnostics in enterprise management system at the present stage of the active promotion of integration and globalization processes in the world. The purpose of the research has identified the key research objectives that will be pursued in the following research methodology: substantiation of the essence of socio-economic diagnostics of the enterprise as an information base for managerial decisionmaking, identification of the priority accents of socioeconomic diagnostics taking into account integration and globalization conditions and challenges, studying the best international experience of the priority kind of diagnostics - diagnostics of financial status of the enterprise, development of an unified methodology for diagnosing the financial status of an enterprise on the basis of recognized international diagnostic standards.

\section{Essence and accents of socio-economic diagnostics}

In the conditions of the active spread of European integration and globalization processes in the international space, there is a shift in the accents of the priority and scale of the diagnostics from the closed evaluation of all functioning areas of micro-level object (enterprise) without taking into account the diagnostic results at higher levels to its target complex consideration of its priority parameters in correlation with macro- and meso-economic objects. It reflects the socio-economic character of the diagnostics, which is represented by a thorough study of the most relevant parameters, vectors and spheres of the functioning of representatives of the micro-level, taking into account diagnostic results at higher levels in accordance with recognized international standards and rules.

Socio-economic diagnostics is an integral attribute of a management system at any level because it is aimed at providing information support for the making and adoption of managerial decisions in the priority areas of the macro-, meso-, and micro-environment. Information purpose of socio-economic diagnostics consists of the preparation of reliable, objective, representative, relevant, complex, and substantiated information provision of the management process at different levels of the national and international economy. Thus, socioeconomic diagnostics forms an informational basis for establishing, providing and expanding the relationships between different subjects of the macro-, meso- and micro-environment at the national and international 
levels, first of all, in the context of the intensification of European integration processes in Ukraine.

The key idea of socio-economic diagnostics in the context of European integration is to assess the retrospective, current, prospective status, and trends in the development of the most relevant areas and parameters of the functioning of representatives of the micro-economic level, taking into account the corresponding recognized and widely used in the international space results of diagnostics of macro- and meso-economic character, which are formed by the authoritative international and European organizations.

Based on consideration of the realities of national economic development and modern problems of domestic business structures, as well as perspective opportunities of European integration for Ukraine, it was found that the most priority areas of socioeconomic diagnostics in the national space are the financial status of enterprises, their insolvency, and the threat of bankruptcy, creditworthiness, and investment attractiveness. This choice is not random but objectively caused by the current problems of the national economy and the necessity of their constructive solution via the opportunities of European integration. Today the massive tightening of payments crisis on different types of liabilities of national enterprises, many stops and liquidations of businesses due to their bankruptcy, lack of sufficient own funds to support the needs of production and economic activity, investment unattractiveness and uncompetitiveness, etc. are not the news. The effective and well-grounded socio-economic diagnostics by the priority spheres will enable to restore the activity of insolvent, but economically viable business structures, to avoid their irreversible liquidation in the structure of the national economy, to expand the access of business entities to domestic and foreign credit resources, to interest national and foreign investors in the development of Ukrainian business, etc. All abovementioned will ensure the formation and strengthening the competitiveness of domestic business and national economy in general, will improve the country's image in the eyes of the European community and, as a result, successful European integration of Ukraine.

Socio-economic diagnostics is characterized by poly-address appointment, because its results can be successfully used by the state and local authorities during making decisions of international, national, and local character, aimed at the development of the national economy and its business in particular, as well as the intensification of international relations; potential investors during selecting the attractive objects of investments; financial and credit institutions during making decisions about lending of borrowers; consulting and audit agencies during formulating complex or partial conclusions about the status of diagnosed objects; contracting parties during choosing new partners or expanding cooperation with existing counterparties; business entities in the process of their current activities to solve different problems and ensure the effective functioning in the market.

\section{International experience of diagnostics of the financial status of the enterprise}

In the conditions of frequent occurrence of various crisis phenomena at the national and international levels, the diagnostics of the financial status of the enterprise takes place as one of the key types of diagnostics. The financial diagnostic is an integral part of the different complex diagnostic objectives associated with the assessment of the bankruptcy threat, insolvency, creditworthiness, investment attractiveness, enterprise's development. That is why today there are many publications that reveal different aspects of diagnosing the financial status of the enterprise. The overwhelming majority of scholars Bhatia (2012), Böninghausen B. and Zabel M. (2015), Elkhoury (2008), Estrella (2000), Galil (2003), Matthies (2013) mostly analyse the best international diagnostic practice, not revealing own views on unified methodological, indicative, criterion, identification, and interpretive provision of diagnostics of the financial status of the enterprise.

The results of the study of foreign diagnostic practice show that the leading players of international markets during the establishing cooperation mainly focus on the diagnostic results of recognized international credit rating agencies, such as Moody's, Standard \& Poor's, Fitch. These agencies permanently form credit ratings for different organizations from around the world, which are mostly used by investors, financial intermediaries, issuers, companies, and financial institutions.

Below, consider in more detail the financial component that is evaluated by credit rating agencies in forming the credit ratings of enterprises. On the basis of thorough study of different methods of rating diagnostics of business representatives from different sectors of the economy, the key factors that specialists of Moody's corporation assign credit ratings to companies, are determined: the size (volume of income) of the enterprise; business profile of the enterprise activity; profitability of the enterprise activity; solvency of the enterprise; financial policy of enterprise's management (Moody's, 2009).

As we can see, more than half of the factors relate to the financial activity of the enterprise. Thus, the profitability factor is estimated through the definition of indicators such as the profitability of product sales, the standard deviation of the profitability of product sales in five years, the return on assets. The solvency factor of a business entity is formed from indicators characterizing the structure of capital (the ratio of the company's debt to the currency balance), the level of debt coverage (the ratio of the debt to the profit EBITDA), the level of coverage of interest expense 
(the ratio of the profit EBIT to the interest expense), cash flow (the ratio of cash flow excluding dividends to the net debt). The factor of the financial policy assesses the level of stability and conservatism of financial management and risk management, stability of the dynamics of enterprise's indicators in the conditions of different external (first of all, economic) factors, protection of the rights of creditors and owners, credit history, etc. (Moody's, 2009).

In general, the Standard \& Poor's credit rating methodology includes assessing the profile of business risks and financial risks, as well as other parameters of the enterprise's activity. The business risk profile is determined on the basis of the estimation of the correlation of potential risks and opportunities of profit receiving for the particular business entity in the market conditions, taking into account the sectoral and public risks, as well as competitive advantages and weaknesses of the enterprise. The profile of financial risks is assessed by the quality of managerial decisions that managers make in the context of the business risk profile of the entity and financial risk tolerance, including management decisions regarding the sources of funding and the structure of the balance sheet, as well as the cash flows generated by the company in relation to financial liabilities. As we can see, the financial component takes the lion's share within Standard \& Poor's diagnostic methodology. The key financial indicators within such diagnostics are the ratio of cash flow and debt load, capital structure, financial policy, liquidity (Standard \& Poor's, 2014).

Diagnostic methodology of Fitch's credit rating agency is based on taking into account key rating factors such as industry risk, operating environment, company profile, management strategy and corporate management, company group structure (for multinational companies), financial profile (cash flows and income, capital structure, financial flexibility) (Fitch, 2015).

Regarding the financial profile of the business structure, cash flows are measured on basis of taking into account cash flow, income, and solvency. The capital structure of an enterprise is determined by the level of financial dependence on external financing sources. The financial flexibility of the company is measured by its ability to repay its debt obligations and manage periods of volatility without deteriorating credit quality. In addition, financial flexibility is determined by such factors as the level of relationship with banks, the ability to redistribute assets and coordinate capital spending plans, the access to credit and equity markets, etc. (Fitch, 2015).

Thus, based on the study of diagnostic methodologies of the leading credit rating agencies Moody's, Standard \& Poor's, Fitch, it can be concluded that the financial component is the most priority for different users of diagnostic results for various diagnostic objectives.

\section{Harmonization of diagnostics of the financial status of the enterprise}

In today's crisis conditions of domestic enterprises' operation, diagnostics of their financial status has an increasing importance, which forms a well-grounded information base about the strengths and weaknesses of financial activity, the threat of its deterioration or prospects for improvement. The management of business structures is extremely interested in obtaining and managing grounded and structured results of financial diagnostics, because on their basis it is possible to make competent management decisions in order to avoid a crisis or overcome it, maintain financial stability, increase profitability, liquidity, business activity, etc.

Figure 1 shows a unified methodology for diagnosing the financial status of the enterprise.

As we know, at the present stage, the indicator base for diagnosing the financial status of business structures is quite broad and has several hundreds of financial indicators from highly specialized to integral. At the same time, the four groups of indicators are most fully characterized the financial status of the enterprise, in particular: profitability, liquidity, financial independence, and business activity.

In particular, the indicator base for diagnosing the financial status of the enterprise consists of:

- indicators of profitability (coefficients of return on capital (assets), own capital, sales of products);

- liquidity indicators (coefficients of general liquidity, rapid liquidity, absolute liquidity);

- indicators of financial independence (coefficients of autonomy, financial leverage, and the system of W. Beaver's indicators);

- indicators of business activity (coefficients of turnover of assets, turnover of accounts payable, termination of accounts payable, turnover of accounts receivable, termination of accounts receivable, the ratio of receivables and payables, turnover of inventories, turnover of own capital, turnover of fixed assets, as well as average terms of repayment of accounts payable and receivable, turnover of inventories).

It should be noted that only by calculating the representative indicators from all four of these financial areas, comparing the actual obtained values with the adequate criteria and competent aggregation into a single integrated indicator can make a complex conclusion about the financial status of the enterprise. Along with the use of the indicator-criterion base, the competent identification of a concretefinancial status of the enterprise andits further interpretation with substantiated recommendations for improving or strengthening become important.

On the basis of the study of the international and national experience of financial diagnostics in the theoretical, practical, and regulatory aspects, it is proposed to distinguish the following types of financial status of economic entities: risk-free status, the status of 
1. Information support for diagnostics of the financial status of the enterprise

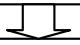

2. Determination of objectives of diagnostics of the enterprise financial status

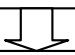

3. Selection of methods of diagnostics of the financial status of the enterprise

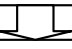

\begin{tabular}{|c|c|c|c|}
\hline \multicolumn{4}{|c|}{ 4. Formation of a system of financial indicators of the enterprise } \\
\hline & & $\rightarrow$ & \\
\hline $\begin{array}{l}\text { Indicators of } \\
\text { profitability }\end{array}$ & $\begin{array}{c}\text { Indicators of } \\
\text { liquidity }\end{array}$ & $\begin{array}{l}\text { Indicators of } \\
\text { financial } \\
\text { independence }\end{array}$ & $\begin{array}{l}\text { Indicators of } \\
\text { business activity }\end{array}$ \\
\hline
\end{tabular}

5. Selection of criteria for financial indicators of the enterprise

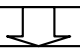

6. Calculation of financial indicators of the enterprise and comparison of their actual values with criteria

7. Interpretation of obtained comparative results by the binomial approach

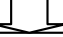

\begin{tabular}{|c|c|c|c|c|}
\hline \multicolumn{5}{|c|}{ 8. Identification of the concrete financial status of the enterprise } \\
\hline & & 1 & & \\
\hline $\begin{array}{l}\text { Risk-free } \\
\text { status }\end{array}$ & $\begin{array}{c}\text { Status of } \\
\text { destabili- } \\
\text { zation }\end{array}$ & $\begin{array}{c}\text { Pre-crisis } \\
\text { status }\end{array}$ & $\begin{array}{l}\text { Status of } \\
\text { technical } \\
\text { default }\end{array}$ & $\begin{array}{l}\text { Status of } \\
\text { actual } \\
\text { default }\end{array}$ \\
\hline
\end{tabular}

9. Formation of structured diagnostic conclusion about the financial status of the enterprise, problems and prospects of its improvement

Figure 1. The unified methodology of diagnostics of the financial status of the enterprise

destabilization, pre-crisis status, the status of technical default, the status of actual default.

Below, briefly describe each of the identified types of financial status of the enterprise on the basis of identifying the most representative trends that characterize it, and providing clear, well-grounded recommendations for solving problems or strengthening strengths in the financial area.

Thus, the risk-free status, in general, demonstrates positive parameters in profitability, liquidity, financial independence of the enterprise, which testifies the absence of any signs of the threat of bankruptcy in the near future. The reason for the diagnosing the insolvency of the entity is the slight deviation in the sphere of general liquidity and business activity, which at this stage do not adversely affect the financial parameters of enterprise's activity and its financial stability.

The status of destabilization reflects the first weak signals of the potential insolvency of the enterprise, which is confirmed by certain negative tendencies in some spheres of financial status; in particular, it concerns either financial performance or the decline of business activity or minor deviations in the general liquidity.

The pre-crisis status represents significant problems in the spheres of financial performance, independence, business activity, and the existence of negative trends in the dynamics, there is a partial deterioration of liquidity, indicating that the company goes to bankruptcy.

The status of technical default reflects the decline or lack of financial performance, deterioration of liquidity, the formation of financial dependence and inappropriate business activity, indicating the existence of obvious "technical" features of bankruptcy. However, at the same time, it is possible to leave the enterprise with such a situation on the basis of realization of a set of well-grounded sanitization measures of financialeconomic, production-technical, organizational and social character aimed at restoring solvency, profitability, structural equilibrium of capital and competitiveness. 
The status of actual default indicates the actual bankruptcy of the enterprise because it is characterized by insolvency, broken structure of capital, lack or insufficient level of financial performance, economic inactivity. This is, as a rule, the voluntary or forced liquidation of an enterprise, recognition of bankruptcy, or reorganization under the influence of external entities in accordance with the current legislation.

It should be noted that the developed identification and interpretation base is complex as it enables to characterize the financial status of the entity in four key spheres of profitability, liquidity, financial independence, and business activity and thus provides an integrated conclusion about the financial position of the enterprise. In addition, the proposed identification and interpretation base is harmonized with the best international diagnostic practice, because it is based on the study of foreign theoretical, regulatory and practical experience in this field with the use of international diagnostic terminology. It will provide a complex, structured, unified, and unambiguous interpretation of the financial status of the diagnosed object by domestic and international subjects.

\section{Conclusions}

In modern conditions of active expansion of integration and globalization processes in the world, international cooperation, including between economic entities, is important for any country. The establishment of effective relations with foreign counterparties is based, first of all, on the unified, objective, and harmonized with international standards information base, which is the result of targeted diagnostics. In today's conditions of crisis phenomena, integration and globalization processes, there is a significant shift of accents in the target priority and the scale of the diagnostics of enterprises. It is about, in particular, the updating of the evaluation of the most important parameters and areas of functioning of business structures, where the significant problems of their activities are traced, as well as the perspective development opportunities, are emerging from the preferences of integration and globalization. Such target diagnostic reality is represented by key parameters of the functioning of domestic enterprises, in particular, financial status, solvency, bankruptcy threats, creditworthiness and investment attractiveness. Based on the study of the best international diagnostic experience, it has been established that the financial component is a priority and accompanies most of the complex diagnostic objectives related to solvency assessment, bankruptcy threats, creditworthiness, investment attractiveness, competitiveness, and enterprise development. On the example of the diagnostic experience of Ukraine as a country on the path of European integration, there are many problems that reflect the discrepancy with recognized international diagnostic standards. Thus, a unified methodology for diagnosing the financial status of the enterprise for the representatives of different countries was developed. In particular, within the framework of the developed methodology of diagnostics of the financial status of the enterprise, it is proposed to calculate four groups of financial indicators: profitability, liquidity, financial independence and business activity. By comparison of obtained actual values of indicators with the appropriate criteria, an identification database for diagnostics of types of enterprise's financial status was developed, including risk-free status, destabilization status, pre-crisis status, the status of technical defaults, and the status of actual default. The developed methodology is based on taking into account the best international diagnostic practice, diagnostic problems of developing countries and their national conditions of functioning, integration and globalization trends and challenges, which will ensure the unification of diagnostic procedures for making managerial decisions by the subjects from different countries.

\section{References:}

Bhatia A.V. (2012). Sovereign credit ratings methodology: an evaluation. IMF working paper, October. International Monetary fund. Retrieved from: https://www.imf.org/external/pubs/ft/wp/2002/wp02170.pdf (accessed 19 May 2018).

Böninghausen B. and Zabel M. (2015). Credit ratings and cross-border bond market spillovers. Working Paper Series of European Central Bank, 1831. European Central Bank. Retrieved from: https://www.ecb.europa.eu/pub/ pdf/scpwps/ecbwp1831.en.pdf?9d0f2bcd6cf9f7aae9af834eb451e29f (accessed 18 May 2018).

Galil K. (2003). The quality of corporate credit rating: an empirical investigation. (Part of PhD thesis). Berglas School of Economics, Tel-Aviv University Center for Financial Studies, Goethe University of Frankfurt. Retrieved from: http://www.mathematik.uni-ulm.de/carfi/vortraege/downloads/Credit_Ratings.pdf (accessed 18 May 2018)

Elkhoury M. (2008). Credit Rating Agencies and their Potential impact on developing countries. Discussion Papers of United Nations Conference on Trade and Development, 186. United Nations. Retrieved from: http://unctad.org/ en/docs/osgdp20081 en.pdf (accessed 17 May 2018)

Estrella A. (2000). Credit ratings and complementary sources of credit quality information. Working papers of Basel Committee on banking supervision, 3. Basel: Bank for International Settlements. Retrieved from: http://www.bis.org/publ/bcbs_wp3.pdf (accessed 19 May 2018)

Matthies A.B. (2013). Empirical research on corporate credit-ratings: a literature review. Discussion Paper 2013-003. SFB-649 Economic Risk. Berlin. Retrieved from: http://sfb649.wiwi.hu-berlin.de/papers/pdf/ SFB649DP2013-003.pdf (accessed 19 May 2018) 
Mykolska N. (2018). Tsikavi fakty pro torhivliu z YeS za I kvartal 2018 roku [Interesting facts about trade with EU in the first quarter 2018]. ISSUU (electronic site). Retrieved from: https://issuu.com/nataliyamykolska/ docs/ukraine_eu_facts (accessed 19 May 2018)

Fitch Ratings (2015). Opredelenija rejtingov i drugih vidov rejtingovyh mnenij Fitch Ratings: perevod $s$ anglijskogo [Definitions of ratings and other rating views of Fitch Ratings: translation from English]. Fitch (official electronic site). Retrieved from: https://www.fitchratings.ru/ru/regulatory/ratings-definitions.html (accessed 18 May 2018) (in Russian)

Moody's (2009). Simvoly i opredelenija rejtingovogo agentstva Moody's: perevod s anglijskogo [Moody's Rating Symbols \& Definitions: translation from English]. Moody's (official electronic site). Retrieved from: https://www.moodys.com/sites/products/ProductAttachments/2007100000528403.pdf (accessed 18 May 2018) (in Russian)

Standard \& Poor's Rating Services (2014). Vse, chto nuzhno znat o kreditnyh rejtingah [All you need to know about credit ratings]. Standard \& Poor's (official electronic site). Retrieved from: https://www.standardandpoors.com/ ru RU/delegate/getPDF? articleId=1498030\&type=COMMENTS\&subType=RATING\%20DEFINITION (accessed 18 May 2018) (in Russian) 